\title{
Modernizing Administrative Procedural Law in Slovenia as a Driving Force of Efficient and Good Administration
}

Polonca Kovač

\begin{abstract}
The article presents the current organization and the past and potential development of administrative procedural law - particularly the General Administrative Procedure Act - in Slovenia from its independence in 1991 till 2011. The author critically evaluates the regulation of general and special administrative procedures in Slovenia in light of the insufficient overcoming of traditional patterns. Namely the regulation in place overprotects the rights of parties and rather neglects the efficiency of administrative procedures as a whole. The evaluations are supported by the development of the theory of governance, radical changes in society and the need for a shift in the understanding of state/authority in the system in Slovenia and other countries (e.g. Finland, Croatia or the USA). The Slovenian system is firstly analyzed using the historical method and later on, it is assessed in terms of the efficiency of administrative procedures as regulated and run in administrative and judicial practice by means of a SWOT analysis. Additionally, particular emphasis is put on the comparative analysis of the Slovenian system to internationally recognized principles in administrative matters, deriving from the experience of the ECHR, the EU Ombudsman code and EU member states, and theory. The main finding is that in comparison, the standardization of parties' rights far exceeds basic rights of defense as framed in constitutional terms which in several ways diminishes the overall efficiency of administration. The author therefore proposes the basis for a multilevel model of governing administrative relations de lege ferenda, intended to regulate in more detail the procedural status of the parties on one side and simultaneously the pursuit of public interest on the other. Based on the latest scientific findings, the criteria for differentiation include: relevance of the subject, degree of conflictuality of interests, need for rationality and efficiency of administration, and the position of the authoritative body. The objective is to move administrative
\end{abstract}


procedural law from the margins of modernization of the public administration as found in the development of the Slovenian system in the last two decades and to make it its driving force, instead.

Key words: administrative procedural law, General Administrative Procedure Act, principles, rights of the parties, public interest, efficiency, modernization, democracy, Slovenia

\section{Definition and development of administrative procedural law in Slovenia 1991-2011}

Regarded as a subject matter of scientific studies or a scientific discipline, administrative procedural law is made up of administrative legal norms that regulate the relations between the parties asserting their rights, legal interests and obligations under administrative law and the authorities (state, municipalities, and other bearers of public authority). The most important legal act governing this field in Slovenia as well as in other countries is the General Administrative Procedure Act (GAPA $\left.{ }^{1}\right)$, which, pursuant to the existing regulation, applies to all administrative matters and even to non-administrative public procedures that are not regulated by a specific act (subsidiary or mutatis mutandis application under Articles 3 and 4 of GAPA).

GAPA was adopted in $1999^{2}$ and began to apply in 2000; prior to that, as well as in relation to procedures initiated yet not completed before its entry into force, Slovenia applied the General Administrative Procedure Act of 1986 (GAPA/86). The latter, adopted as early as 1956 and last amended in 1986 in former Yugoslavia, was largely replaced by the GAPA of the Republic of Slovenia almost a decade after the country had gained independence. Experts note, however, that despite radical changes in the social and economic relations, there are no major conceptual divergences between the two acts. ${ }^{3}$ As a matter of fact, a more radical modification of GAPA/86 would be expected considering the new ideas about the functioning of the society and its values, the altered role of the state and authority therein, and the different structures and functions of public administration. Certain authors argue

1 Official Gazette of the Republic of Slovenia No. 80/99, 70/00-ZUP-A, 52/02-ZUP-B, 73/04-ZUP-C, 119/05-ZUP-D, 24/06-UPB2, 105/06-ZUS-1, 126/07-ZUP-E, 65/08-ZUP-F, 8/10-ZUP-G.

2 The territory of today's Republic of Slovenia is by tradition deeply committed to the regulation of administrative procedure: since 1923, the relations between authorities and individuals had been regulated by the general principles of administrative procedure (by Steska), and since 1930 by the relevant law within the Kingdom of Yugoslavia. Hence, Slovenia has been applying GAPA for over 80 years, which makes it one of the oldest and most important acts that apply to all (not only administrative) public-law relations (more in Jerovšek and Kovač 2010).

3 Cf. Jerovšek 1999, Koprić 2005, Rusch 2009. The authors compare the existing Slovenian regulation with the former Yugoslav GAPA, with similar acts in the former Yugoslav republics and EU countries, and with the Austrian law of 1925. They note a certain degree of similarity, which is probably due to the fact that Slovenia preserved the tradition and complexity of the Yugoslav regulation of general administrative procedure that also resulted in a significant amount of case law (Koprić 2005, 2). 
that some good opportunities had been missed. ${ }^{4}$ Another reason for such continuity might be the remarkable degree of contemporariness of GAPA/86 and its weak ties with the values of the socialist system of self-management and political neutrality, which is why no major reform was needed in this respect. Since fair procedure is intended as an expression of democracy and the country's orientation toward the users of public services, Slovenia saw no pressing need to design a new GAPA based on the model of other countries ${ }^{5}$, and several years passed before it adopted an act of its own ${ }^{6}$; likewise, the revision of GAPA was not directly related to the other measures of reforming public administration.

In order to assess and update the regulation of administrative relations, it is necessary - parallel to GAPA - also to pursue and advance the regulation of the basic forms of judicial control over the legality of individual acts issued in procedures completed pursuant to GAPA, such as administrative dispute ${ }^{7}$, constitutional complaint $^{8}$, and protection before the European Court of Human Rights (according to the European Convention on Human Rights ratified by Slovenia in 1994). In Slovenia, the administrative judiciary has been operating based on the Yugoslav tradition ever since the creation of the independent state, initially under the general Supreme Court and since 1998 as a specialized court (Administrative Court of the Republic of Slovenia) enabling better accessibility for the parties and more focus on

4 Likewise Koprić and Đulabić (2009) critically assess the new Croatian GAPA of 2009, considering it inconsistent with the trends of modernization, Europeanization, and rationalization or informatization of (Croatian) public administration, although - in terms of reduction of overregulation, introduction of administrative contract, reform of legal remedies, etc. - it is more radical than its Slovenian equivalent.

5 In addition to the USA (1946), administrative procedure acts were adopted in Japan (1967), Spain (1889 - amended in 1958 and 1992), Austria (1925 - amended in 1991), the Czech Republic and Poland (1928 - amended in 1960), Hungary (1957), the Netherlands, Norway and Switzerland (1967 - in the Netherlands amended in 1994), Bulgaria (1969), Sweden (1971 - amended in 1986), Germany (1976 - last amended in 2008), Sweden and Denmark (1986), Italy (1990), Portugal (1991), Iceland (1993), Finland (2003), Kosovo (2005) and Croatia (2009). Partial codification applies in the UK (1958 and 1966), the former Soviet Union (1968) and Romania (1970), whereas no (full) codification exists in Belgium, France (only a code), Greece or Ireland (Jerovšek 1999, Ziller 2005, Koprić and Đulabić 2009, and Rusch 2009).

6 Other former Yugoslav republics adopted their general administrative procedure acts even later (Koprić and Đulabić 2009, 26). A new GAPA was adopted by SR Yugoslavia in 1997 and has been used since 2003 by today's Serbia whereas Montenegro adopted its own GAPA in 2003. In Bosnia and Herzegovina, a new GAPA was adopted by the BIH Federation in 1998 and by Republika Srpska, Brčko District and BIH in 2002. Macedonia and Kosovo adopted GAPA in 2005. Lastly, GAPA was adopted in Croatia in 2009 (after three years of cooperation with an international expert group) and began to apply on 1 January 2010.

7 As provided since 2007 by the Administrative Dispute Act (ZUS-1, Official Gazette of the Republic of Slovenia No. 106/05, 26/07 Skl. US, 122/07 Skl. US, 65/08 Odl. US, 119/08-Odl. US, 54/09-Odl. US, 107/09-Odl. US, 14/09-Odl. US, 62/10-ZUS-1-A) and before that by the former Administrative Dispute Act (Official Gazette of the Republic of Slovenia No. 50/97 and amendments).

8 Acc. to the Constitutional Court Act (ZUstS, Official Gazette of the Republic of Slovenia No. 15/94, 64/01-ZPKSMS, 51/07, 64/07-UPB1, 108/07-Skl. US). 
administrative matters. ${ }^{9}$ Thus, upon demonstrating legal interest not only directly in the case but also in order to improve their legal position by challenging the contested administrative act or with reference to the encroachment on constitutional rights or fair procedure and other ECHR provisions ${ }^{10}$, the parties in administrative matters in Slovenia have been guaranteed four-level legal protection since the amendment of the Constitutional Court Act and the Administrative Dispute Act. Related issues (according to GAPA) include openness of work of the administration, user counseling (as provided by the Decree on Administrative Operations ${ }^{11}$ ), personal and confidential data protection, regulations concerning the organization and (delegation of) task(s) of the administration, etc. Moreover, in theoretical terms - owing to derogations from the principle of equal protection of rights (Article 22 of the Slovenian Constitution, cf. Harlow and Rawlings 1997, 181), and in practical terms - considering the accelerated development and growing list of sector-specific regulations, mention needs to be made also of the regulation of special administrative procedures, with individual provisions or entire chapters concerning the assertion of the parties' rights and obligations in otherwise predominantly substantive sector-specific laws. For the moment, the only integrally regulated special administrative procedure in Slovenia is the tax procedure which - with clearly specified grounds for derogation from the general norm proposed by GAPA - is regulated by its own act of 1996 (current applicable version: ZDavP-2, Official Gazette of the Republic of Slovenia No. 117/06 and amendments, with over 400 articles containing also substantive law provisions; more in Jerovšek and Kovač 2007).

Although GAPA was adopted already in 1999 while the Administrative Dispute Act, the amended Constitutional Court Act and the Tax Procedure Act followed seven or eight years later, the remaining corpus of basic legislation concerning administrative procedure in Slovenia is consistent with the provisions of GAPA and its subsequent amendments as well as with the relevant implementing acts (e.g. Decree on Administrative Operations). Thus, for example, the Administrative Dispute Act (applying since 1 January 2007) takes account of the need for prompt final-

9 Other countries have different systems of judicial control over the actions of the administration; a rough distinction is made between a) the group of countries without a specialized administrative court (Denmark), b) the group of countries where administrative control is exercised by general courts with special administrative sections (e.g. Spain, Netherlands, Slovenia until 1996), and c) the group of countries with specialized administrative courts (France and its Conseil d'Etat, Sweden, Italy, Germany, Belgium, Greece, Portugal) (Ziller 2005, 265).

10 In addition to the actual legitimacy, the claimant - in order to be granted legal protection - also has to show that he/she has legal interest (cf. Breznik et al. 2008). Also Craig $(2005,272)$ : "The claimant will none the less have to show that he or she has an interest which is sufficient to trigger the applicability of procedural rights ... [It] will have to be shown that the claimant has a life, liberty or property interest that has been affected by the agency action complained of.

11 Official Gazette of the Republic of Slovenia No. 20/05 and amendments. The Decree regulates certain issues that have a weak basis in the Act (e.g. extension of limited local jurisdiction, e-serving vs. traditional forms of serving or information), yet serves as a "citizen charter" since it introduces in the relations between administrative bodies and private parties modern principles of openness, support, cooperation, etc. 
ity and enforceability of administrative law relations and upgrades GAPA with the principle of two-level decision-making pending finality, thereby limiting the appeal in administrative dispute exclusively to the protection of constitutional rights and freedoms and the establishment of a different state of affairs in court (Article 73 of the Administrative Dispute Act). In terms of reasonable time for decision, the provision of the same Act is rather crucial, stating that the appellant may invoke administrative silence regardless of the possible continuous performance of procedural actions before administrative bodies if within three years no final administrative decision on the merits or no order to suspend the procedure has been issued (Article 28(3) of the Administrative Dispute Act).

As regards the internal consistency of administrative procedural acts in Slovenia, it needs to be stressed that GAPA, the Administrative Dispute Act, the Tax Procedure Act and other key acts were (almost) always integrated or at least mentioned in strategic documents on the reform of public administration issued between 1996 and 2010, yet never featured as pillars of development. ${ }^{12}$ Nor did - in terms of time or substance - the preparation of GAPA and the Administrative Dispute Act correspond with the main legislative reform projects (e.g. the principles enshrined in the Act on Civil Servants - who are considered official persons by GAPA - are inconsistent with the basic principles of GAPA; the status of government services under GAPA is inconsistent with the provisions of the Act on State Administration, etc.). The greatest emphasis on the significance of administrative procedural law in this context was given by the 1996 parliamentary strategy aimed at reforming the Slovenian public administration to meet the requirements of EU membership (Slovenia became a full EU member on 1 May 2004), which defined the revision and adoption of the Slovenian GAPA as a foundation of the democratic system of protection of individuals against the possible abuse of power, together with judicial control over the administration and a non-formal ombudsman. Strategic documents adopted after 2002 only partially define administrative procedural law and rather refer to removing administrative burdens and simplifying the procedures and the organization of the administration (e.g. by means of a single entry point) (Kovač 2010b). Therefore, administrative procedural law should not be underestimated as a part of the overall functioning and modernization of public administration, since:

12 See the Strategy of Accession to the European Union (1996, Poročevalec DZ RS, No. 48/97 and 48/I/97, 61-73 and 168-207), the Strategic Plan for the Implementation of the Public Administration Reform (1997-1999) - in relation to EU accession, the Strategy of Further Development of the Slovenian Public Sector (2003-2005), the Slovenian Development Strategy (2006-2013), the Slovenian Crisis Exit Strategy (2010). Some traces of interest in administrative procedure can be found only in relation to the definition of state (or municipality) as an economic development player, where the administrative burden in the functioning of the administration is identified and reduced (similarly outside Slovenia at the level of OECD and the EU, Kovač 2006). The situation in other countries is different, e.g. in Croatia, the new GAPA was one of the five elements of the Strategy of State Administration Reform 2008-2011 (Koprić and Đulabić 2009, 23). 
- it represents a key business process (a basic function of state administration, municipalities and bearers of public authority; also Rusch 2009, 4, defining the regulation of administrative procedural law together with the rational organization of public administration and the public-servants system as a sound reform);

- it largely implies the exercise of constitutional safeguards (cf. Ziller 2005, 261; such as the rule of law, equality before the law and equal protection of rights, exercise of fundamental human rights and freedoms, effective legal remedy, protection of the Slovenian language, legality and sovereignty, hierarchy of acts, administrative dispute, prejudicing final decisions, etc.).

\section{Significance of subsidiary and mutatis mutandis application of GAPA in public-law relations}

The aim of regulating administrative procedures is to regulate the manner in which the parties, in their relations toward the authorities, assert their rights, legal interests and obligations under substantive administrative law. Normally, such relations are regulated specifically and in much detail, as they imply a confrontation of and collision between private interests of the parties as legitimate holders of rights and obligations on one side, and public interest on the other, the protection of which is to be guaranteed by administrative bodies performing public tasks. ${ }^{13}$ GAPA thus also represents a tool to design public policies for the development of the state. Therefore, even the subsidiary or mutatis mutandis application of GAPA in nonadministrative matters - if the issue is not regulated by the relevant act in a publiclaw procedure - is highly significant.

Applied since 2000, GAPA - in the part where its application is imposed through the definition of administrative matter and through the subsidiary and mutatis mutandis application of the Act (Articles 2-4 of GAPA) and the relevant case law in the administrative dispute concerning the providers of public services (e.g. Constitutional Court case U 1375/95-6 and Supreme Court case I Up 131/02) - represents a considerable derogation from the former regulation. In other words, by extending the application of GAPA to "indirect administration", the position of the parties strengthened although there are theoretical and practical considerations as to the application (although mutatis mutandis) of GAPA in otherwise lex-artis procedures (conducted based on the standards of respective professions, such as teaching, medicine, chimney-sweeping, etc., cf. Kerševan 2003). Moreover, given the traditional effectiveness of this act, Slovenia also provided for a mutatis mu-

13 According to the Slovenian legislation, the protection of public interest is not a necessary dimension of administrative relations since the formal criterion - the relation between authority and subordinate parties - is also a constituent one. On the other hand, public interest is an indispensable and not merely supplementary element leading to the application of GAPA in a substantively defined administrative matter. More in Androjna and Kerševan (2006, 51-55), cf. also Pavčnik $(2007,117)$. 
tandis application of GAPA in misdemeanor cases (since 2005 in procedures before administrative bodies) or civil servants' law (2006). Yet major dilemmas arise as regards the mutatis mutandis application of GAPA. It is not clear which cases (not regulated by the relevant acts) GAPA covers, nor which parts or institutions of GAPA are (not) appropriate. The mutatis mutandis or appropriate application of GAPA is thus indicated by case law, e.g. in relation to the principle of examination of parties, procedures with incomplete applications, or the obligation of delivering reasoned decisions (in general Schwarze 1992 and Harlow and Rawlings 1997, for Slovenia see Androjna and Kerševan 2006 and Jerovšek and Kovač 2010).

On the other hand, subsidiary or mutatis mutandis application of GAPA means that it applies in its entirety unless the sector-specific act provides otherwise in a given case. Yet the constitutional principle of equal protection of the rights of the parties requires that in individual administrative matters, the procedural position of the parties does not depart from the regulation of GAPA unless material and formal conditions have been met, which since 1992 has also been assessed by the Supreme and Constitutional Courts (e.g. Supreme Court case U 593/93-6, U-I287/95, Up-147/96, U-I-252/00, see also Kovač 2010b). These conditions are:

- material: withdrawal (e.g. non-suspensiveness of appeal) requires reasonable ground, assessed by means of legitimacy and proportionality checks; as regards the latter, the sector-specific intervention must preserve at least the corpus of nine basic principles of GAPA (Articles 6-14, from legality to economy);

- formal: as a supplement to or different from GAPA, the procedure can be regulated only by a sector-specific law and no minor act; in addition, only an individual procedural issue can be regulated in this manner and not the entire (particularly administrative) procedure.

According to the Constitution, the rights and obligations of individuals, particularly in their relations toward the authorities when interfering with the legal positions of the parties, can only be regulated by law and not by a minor regulation (and even less by internal administrative instructions, cf. Ziller 2005, 267), as only in this manner is it possible to achieve the predictability of relations (the rule of law) and to perform a review of the constitutionality or legality of a regulation. ${ }^{14}$ An implementing act could regulate the relations between parties and bodies only based on an implementing clause in the relevant law. Moreover, this should only apply to technical issues or individual institutions - thus, it should not be possible,

14 The criteria for recognizing a right or imposing a duty or the administrative procedure can thus be regulated - consistently with the Constitution - only by law and not by an administrative regulation or even a general legal act implementing public authority (e.g. schools; more in Šturm 1997 and Jerovšek 1999). Unfortunately the situation in practice is often different - in the first five years since its establishment (before 1996), the Constitutional Court has annulled as many as four laws (e.g. on citizenship and RTV Slovenia) and 38 implementing regulations of the government or ministries on grounds of violations of the principles of legality and separation of power. 
for example, to change the manner of serving decisions merely by an act of the government or to define the status of parties in the procedure (particularly the substantive legitimization of accessory participants) only by a general act issued by a public agency. The tendency of sector-specific regulations that interfere with the status of the parties in individual administrative cases needs to be critically evaluated, mainly because of their inconsistency with GAPA when a different regulation is neither necessary nor justified. Over the last few years (of economic crisis), such attempts have been quite frequent, triggered by political pressures to shrink administration and by the need for an easier implementation of the rights of e.g. providers of economic activities. ${ }^{15}$

\section{Main changes of GAPA - from goals to implementation}

\subsection{GAPA development goals in the European (and broader) context}

Roughly speaking, the development of administrative procedural law in the world is based on the following complementary objectives:

- to protect the rights of the parties before the state or authority; and

- to pursue public interest through the most effective administrative procedure.

Thus, in administrative procedure, it is necessary to (promptly) recognize a right or legal interest or to impose an obligation to the party if the actual circumstances of the case meet the necessary legal requirements; it needs to be made sure, however, that the parties are guaranteed an adequate procedural status to defend their (legal) interests. On the other hand, most states - at least at a declaratory level - seem to prefer the opposite: the administrative procedure should provide for the protection of the fundamental rights of the parties, whereby it leads to the implementation of rights, legal interests and obligations as defined by positive substantive administrative law. Such a dual perception of the administrative procedure as an instrument of protection of parties' rights and of implementation of public interest is typical of all systems regardless of their legal framework, although in the Anglo-American system, GAPA initially merely protected the rights of the parties and only at a later stage became an instrument of implementation of the tasks of

15 Examples in Kovač (2010a), e.g. normal serving according to the Agriculture Act or shortened fact-finding procedure according to the Kindergarten Act, partial and inconsistent regulation of recognition of foreign diplomas or questionable regulation of the use of language according to the Aliens Act. Similar circumstances are noted for Croatia by Ljubanović (in Koprić and Đulabić $2009,147)$, where special administrative procedures are introduced by over 60 acts. 
administrative bodies. ${ }^{16}$ The administrative procedure is thus part of the administrative process, which is considered a system of conscientious orientation of social interactions, i.e. of regulation on the basis of values of authorities, or a transition from sein to sollen, ${ }^{17}$ which is particularly important given the growing extent and complexity of the tasks of state administration (Craig 2005, 270, similarly Hopkins 2007, 713). Schwarze $(1992,1175)$, for example, states the criteria of the German Federal Constitutional Court, whereby GAPA is constitutionally satisfactory as long as it provides effective protection of the basic constitutional rights and freedoms, although the author argues that it should aim at balancing the protection of parties' rights and public interest with the efficiency and effectiveness of the procedure as such. Therefore, some authors believe that over time, judicial control over administrative acts should comprise not only control of legality but also the assessment of compliance of decisions of the competent agency with its mission - not only legality but also the soundness of decisions in fact testifies to the democracy of relations between authorities and private parties.

Since the administrative relation is by its origin unilateral, GAPA is supposed to protect the weaker party in its relation toward the administrative body or authority. The purpose of administrative procedure is (was) traditionally (since the French Revolution in 1789) to assert the principle of legality, i.e. the authorities' boundedness to applicable and publicly known law, and thus predictability for the parties and consequently the limitation of possible arbitrary authority (Ziller 2005, 261, highlighting the difference in development of the German Rechtsstaat as opposed to the police state and the French theory of democracy with separation of powers). This also applies to development since most changes are based on a well-regulated administrative procedure because of the primary need for legality, impartiality, fair procedure, right to defense, etc. (cf. Schwarze 2004, Craig 2005, 270). In this regard, as early as 1977, the Council of Europe adopted Resolution No. 77 (31) on the Protection of the Individual in Relation to the Acts of Administrative Authorities, later supplemented with a number of other recommendations (CM/Rec (2007)7 on good administration, $\operatorname{Rec}(2003) 16 \mathrm{E}$ on the execution of administrative and judicial decisions, $\operatorname{Rec}(2004) 6$ on the improvement of domestic remedies and $\operatorname{Rec}(2004) 20$ on judicial review of administrative acts, etc.). Particularly important is Article 6 of ECHR on fair procedure, also applicable to administrative practice. In defining an

16 The regulation of administrative procedure is necessarily politically bound, cf. McCubbins et al. $(2007,5,16)$. Authors quote, for example, the report by the US Congress stating as early as 1947! (the US Administrative Procedure Act was adopted in 1946) that the Administrative Procedure Act is an act that guarantees "fairness in administrative operation" as well as "the effectuation of the declared policies of the Congress." Something similar applies for the further development of GAPA or the relevant procedural regulation in light of implementing values and goals of the governing political option.

17 More in Godec $(1993,19)$ and Šturm (in Godec 1993, 97-112). Administrative systems act as a sum of orientating (political level) and orientated (administrative structures) elements, among which there is continuous interaction. 
administrative matter at the level of the EU, two decisions of the European Court of Justice as the court of first instance are important (from Cananea 2003, 568, CFI, Case T-64/89, Automec (1990) and Case T-54/99, max.mobil Telekommunikation Service $\mathrm{GmbH}$ vs. Commission) which - by defining matters as administrative extended the scope of application of administrative procedure in EU institutions from what it had hitherto been. At the international level, case law and recommendations have been emphasizing the necessity of protecting the rights of the parties for decades and have been followed by binding supranational and national legal acts, such as the EU Treaty in the field of competition, state aid, civil servants (Cananea 2003, 563, Schwarze 2004, 86, Statskontoret 2005). The impact of globalization on national law is significant, owing to the need for justice or legitimacy as well as efficiency of administrative actions, and at least a regulatory ${ }^{18}$ convergence of development of administrative law in individual countries is evident although we cannot speak of a unification or harmonization of "European" administrative procedural law. Formal or procedural legality is also very important in countries such as the UK and Ireland, which - contrary to the francophone (where administration is perceived mainly as an issuing of acts) or the German-Nordic circle (defining administration by activity) - understand the importance of the procedure in the issuing of general or special legal acts (Ziller 2005, 262, Rusch 2009, 5). Following similar trends, the EU developed what is known as the right to good administration (Article 41 of the EU Charter of Fundamental Rights). The purpose thereof is to guarantee every person or every legal entity the right to have their affairs handled impartially, fairly and within a reasonable time, whereby they must have the right to be heard and to have access to their files, while the administration must give reasons for its decision. ${ }^{19}$ Based thereon, the need for a codification of the administrative procedure gained strength not only to ensure predictability for the parties but also to prevent maladministration, which does not necessarily mean an illegal or uncon-

18 The existence and subject matter of GAPA does not differ considerably with regard to the level of development of democracy in individual countries, although particularly transition countries show a clear difference between their declared objectives and the goals implemented in practice (Koprić and Đulabić 2009, 31, Rusch 2009, 4).

19 "1. Every person has the right to have his or her affairs handled impartially, fairly and within a reasonable time by the Institutions, bodies and agencies of the Union..

2. This right includes:

a) the right of every person to be heard, before any individual measure which would affect him or her adversely is taken;

b) the right of every person to have access to his or her file, while respecting the legitimate interests of confidentiality and of professional and business secrecy;

c) the obligation of the administration to give reasons for its decisions.

3. Every person has the right to have the Union make good any damage caused by its Institutions or by its servants in the performance of their duties, in accordance with the general principle common to the laws of the Member States.

4. Every person may write to the Institutions of the Union in one of the languages of the Constitution and must have an answer in the same language." 
stitutional act but also a decision which is inconsistent with the legal arrangement as such. Maladministration is prosecuted by the European Ombudsman with a code adopted in 2001 and amended in 2005 (with limitations, owing to the "eclecticism" of provisions, as stated by Hopkins 2007, 725). ${ }^{20}$

Because of due procedural actions carried out by both the administrative body and the party, the administrative procedure also represents a form of catharsis (cleansing) since - if properly conducted - differing interests are confronted therein, and as a rule, despite the possible interference with the status of the party, divergences are settled and a priority of interests is defined more or less consensually. According to Ferk $(2007,75)$, law is a justice-oriented, generally binding, abstract regulation of typical human relations within a society or political social group. In this context, law is seen as a delimitation of powers, differing from a mere authoritative regulation in the sense that it provides the essence of the legal system at least in striving for justice. GAPA thus contributes to the rule of law since authoritative decisions are observed more consistently. Irrespective of the supremacy of public over individual interest, the system of administrative procedure rules (just like administrative law in its entirety) is by its nature one of the most important mechanisms of protecting the rights of the parties and thus of implementing the principle of orientation toward the parties. Related thereto is the doctrine of good governance. Considering the decades-long theoretical and practical modification of the definition of (good) governance with participative strategic partnerships in the economy and civil society ${ }^{21}$, a considerable amount of regulation in the field of administrative procedural law is also attributed to such processes. Schuppert (2011, 289) even distinguishes between two systems of power: on the one hand the government with hard public law, exclusively public law regulators, a state-central system of democracy and parliamentary hierarchically-led reforms, and on the other a system of governance with soft law that is equal to private law and adopted together by public and private entities, with democratic reforms carried out as socially justified by means of networking and open structures (cf. Hopkins 2007, 713). In this context, administrative procedural law should develop in co-regulation procedures with the parties and in terms of subject matter allow for a mutual coordination of possibly opposing interests. In a system of good governance, the state (only) provides authority (and protection of general social good) and is not its exclusive or primary bearer. The state also focuses - or at least it should - (proportionately to public interest) on promoting alternative dispute resolution (e.g. in the case of the

20 European Ombudsman. 2005. European Code of Good Administrative Behaviour. Luxemburg: Office for Official Publications of the European Communities, http://www.ombudsman.europa. eu/code/pdf/sl/code2005_sl.pdf (accessed 3 May 2011).

21 Dealt with by Schuppert $(2011,287,298)$ at the level of regulation transferred by the authorities to other entities by means of delegation, co-regulation, self-regulation, etc., and at the level of implementation by means of public-private partnerships. The author speaks of statehood as a product, which should call for a quality result and constant improvement of the production process. 
German GAPA with administrative contracts). ${ }^{22}$ Under the theories of governance and administration, the concept of legitimacy - affected by globalization and growing social complexity - becomes increasingly important (GAPA should represent a proof of legitimacy according to Hopkins 2007, 720 and Considine and Afzal 2011, 374,380 ). Theory highlights both the parties' participation and impartiality as elements of a democratic legal system (audi alteram partem, nemo iudex in causa sua), as well as an additional fair distribution of public good, transparency and judicial control, rationalization of administrative work and impact of networking, although despite such principles being part of the nature of law, the administration should not implement them contrary to positive established law (Craig 2005, 271).

Over the past few years, several authors have been highlighting the significance of rationality and efficiency of procedures either in the sense of implementing public interest or the mission of administrative bodies or in terms of, e.g., economic development, mitigation of economic crisis, investment capacities, etc. (cf. Rusch $2009,5)$. Weber speaks of technical rationality in the sense of achieving the goals (German: Zweckrationalität) when the administration or its activity is rational and the expected results exceed the burden, as well as of value rationality (German: Wertrationalität). In administrative procedure, there is the necessity for a tradeoff between efficiency and fair results. In this context, theory develops the issue of contestability or adjunction. ${ }^{23}$ Here it is particularly important to know that an advance full guarantee of procedural safeguards in the absence of dispute or problems leads to an (unnecessary) waste of time and resources and restricts the adaptability to achieve the goals of the administrative body (e.g. an over-detailed reasoning,

22 In this regard, cf. the Council of Europe Recommendation Rec(2001)9 of the Committee of Ministers to member states on alternatives to litigation between administrative authorities and private parties. Some degree of caution is needed here, since constitutional law practice in Austria, for example, states that consensual regulation of relations in classic administrative matters leads to a different treatment of equal or comparable positions, which is constitutionally impermissible. Quite similarly, Pitschas and Walther $(2008,99-102)$ find that equality in publiclaw relations is an illusion, although the asymmetry between the parties, i.e. the superior public law entity, strives for that. In administrative dispute (after a final decision in administrative procedure), the parties - although the respondent party is a public law entity i.e. issuer of the administrative act - are equal before the court; here, the audi alteram partem principle applies (Breznik et al. 2008, comment to Articles 21, 22 and 43 of the Administrative Dispute Act) although the respondent party is supposed to represent public interests. Therefore, in an administrative matter, settlement is more likely in an administrative dispute than according to GAPA. Article 137 of GAPA speaks of settlement, yet only between parties with opposing interests. Yet legality is what truly matters pursuant to GAPA and the Administrative Dispute Act; the administrative body may only change its decision if it is contrary to positive law and not for balancing public and private interests. Harlow and Rawlings $(1997,391)$ argue that the mere reduction of the burden of the competent bodies is not a sufficient reason for alternative dispute resolution, although this applies throughout the world.

23 More in Harlow and Rawlings 1997, 502-505, 515-519. See also Koprić and Đulabić 2009, 29 : according to Luhmann 1992, dealing with the issue from a different perspective and advocating the need for the transfer of long complicated procedures to the court - so that administration can focus on productivity. 
Harlow and Rawlings 1997, 523). Despite the latter, the efficiency of public administration is only legitimate if it implies justice and legality, meaning that the opposition between economy and (formal) legality (i.e. due process) might be a fake dilemma. Legitimacy is in fact based on the rationality and legality of authoritative decisions (McCubbins et al. 2007, 3). For this purpose, SIGMA (cooperation of EU and OECD) developed a model GAPA in $2005^{24}$ for the countries which have not codified their general administrative procedure or wish to update it. Despite the direct applicability of common law in the EU Member States, Slovenia and other countries still preserve a considerable degree of sovereignty of national solutions in procedural law (more in Kovač 2006, on the absence of a "European administrative procedure" also Schwarze 2004), and common recommendations are an important directive for national regulators as to when and if administrative procedural law is to be changed. The main message thereof is to pursue the balance or duality of guarantees, both of public interest and the rights and legal interests of the parties and interested persons (Statskontoret 2005, 78), regardless of the order (of development through time or supremacy in the event of collision) of both protected categories.

\subsection{Institutions of the Slovenian GAPA under modification}

The above trends were also followed by the Slovenian legislature, which based GAPA on the Austro-Hungarian tradition aimed at protecting the party in a situation of a priori supremacy of authoritative bodies. ${ }^{25}$ Between 1991 and 2011, however, most amendments regarding GAPA, sector-specific procedural provisions and regulations on judicial control over the administration in Slovenia focused on promoting the efficiency of administrative decision-making, i.e. the technical rationality according to Weber, rather than on protecting the constitutional safeguards of the individuals. This trend is understandable since in Slovenia, the degree of protection of the rights of the parties - at least at a regulatory level - has been traditionally high, while the need for (more) efficiency in the administrative procedure and work of public administration in general has been stimulated over the past few years

24 Sigma. 2005. Checklist for a General Law on Administrative Procedure. Paris: Sigma. Referred to in the following text as "Sigma 2005". A good GAPA should be based on constitutionals safeguards, it should be precise yet not over-detailed, it should specifically regulate administrative dispute. The Act should comprise principles, mainly the principle of examination of the parties, the factfinding and evidence-gathering procedures should be simplified, the status of the parties and accessory participants should be defined. Sigma upgrades the analyses and recommendations by presenting the basic standards and novelties in EU regulation at regional conferences (cf. Koprić 2005, Rusch 2009).

25 Slovenia's regulation largely relies on the Austrian and Yugoslav traditions that emerged after World War I. The same applies to Croatian, Czech, Hungarian and other laws of Central Europe. All those countries were subject to the German doctrine of administrative law being part of constitutional law; the two together constituted the national law, which governed the activity of administrative bodies falling under the executive branch of power. Under this doctrine, the main focus was on the principle of the administrative act (for more details and alternatives see Schuppert 2000, 772). 
mainly by the economy, either in the pursuit of greater competitiveness or in order to overcome the impacts of the economic crisis.

Compared with GAPA/86, the (mostly non-conceptual) modifications introduced by the new GAPA since April 2000 included (Jerovšek 1999):

- designation of (new) competent bodies for two-level decision-making (largely owing to the two-tier system of state and municipalities introduced in 1995), including supervisory right and assumption of jurisdiction in the event of administrative silence;

- definition of administrative matter and the subsidiary and mutatis mutandis application of GAPA;

- redefinition of the basic principles (e.g. added discretion, supplementary examination of the party, definition of legal interest, suspended efficiency, transfer of completeness and finality and use of language as a rule, new principle: the duty to tell the truth and fair exercise of rights);

- determination of the (date of) beginning of the procedure and the procedural conditions for such;

- encouragement of participation of all persons with the status of party (including accessory participants and representatives of public interest) in the procedure;

- reduction of legal remedies (appeal and five extraordinary remedies) and the reasons for that in order to improve legal certainty;

- transfer of more detailed regulation onto implementing acts (e.g. regarding the costs of procedure).

The amendments adopted in 2002-2010, on the other hand, most often focused on the reduction of administrative burden, i.e. facilitated procedural efficiency from the viewpoint of public interest or (only) active parties (critically thereon Kovač 2010b), such as:

- exchange of information from official records held by administrative bodies, seen as a burden for such bodies rather than for the parties (2002);

- obligation of the parties to participate in the procedure with representatives (2005);

- introduction of e-communication (2005, from e-applications to videoconferences and e-serving);

- more efficient serving channels considering the effects of served documents (2005, 2008);

- reduced deadlines for legal remedies (2005, e.g. from five to only three years in renewed proceedings);

- introduction of administrative certification in the taking of evidence (2005); 
- legalization of the renunciation of the right to appeal (2008);

- mitigation of conditions for officials (2008);

- execution competences of the body of first instance (2005);

- increased competences of the administrative inspection (2010 - in response to the rather inefficient partner role of the inspection introduced in 2005).

A small number of amendments related to increased rights of (all) the parties, e.g. the right of access to the file and access to public information (2005), enhanced protection of accessory participants (Article 142 of GAPA 2005), or restricting the serving to official announcement (2010).

The modification of the Slovenian GAPA thus follows the trends recorded in Europe: the protection of the rights of the parties is considerable, and the idea that administration is not or needs not be particularly efficient has been overruled. ${ }^{26}$ Yet over the last 20 years, there has been no major change in the regulation, neither in terms of extent ${ }^{27}$ nor in terms of subject matter. More significant changes can be observed in administrative dispute, also in relation to the greater efficiency of procedure since the new Administrative Dispute Act (2007) introduced the administrative decision on the merits as an act of intervention and subject to challenge before the court (based on the German theoretical definition of administrative act), redefined the parties (e.g. the state is sued if the final decision in a case was taken by a state body), significantly restricted participation (also legitimization for appeal in the protection of public interest), reduced the possibility of appeal to only two extraordinary legal remedies, etc. (more in Breznik et al. 2008).

According to Pollitt and Bouckaert (2001), any reform must be evaluated as to the objective pursued, which is either to maintain (what is functioning well), modernize (i.e. harmonize the operations with broadly accepted concepts and standards), marketize (bringing the public sector closer to the principles and operations of the private sector), or minimize the public share. The modifications of the Slovenian GAPA can thus be categorized under several targets: the prevailing rationalization and wish for greater efficiency (minimization) on the one hand, and the confirmation of the existing regulation by intensifying legal protection of the interests of the parties in the procedure (maintenance) on the other. Nevertheless,

26 On the economy and efficiency of the procedure in more detail, cf. Schuppert 2000, 783-787.

27 An interesting object of comparison is the analysis made by Koprić and Đulabić $(2009,44)$, stating that although the number of articles and provisions is not the only relevant criterion, there are some key differences between individual countries. For example, the Swedish law of 1986 has 33 articles and approximately twice as many provisions, the Finnish law of 2003 has 71 articles and over 140 provisions, the Austrian (1991) and German (1976) laws have just over 100 articles, the Portuguese law (1991) has 189 articles and 406 provisions, the Croatian law (2009) has 171 articles and almost 600 provisions. An over-specified regulation might hinder modernization and lead to bureaucratization, i.e. provide formal support to bureaucratization in relation with the parties and social players rather than encouraging an assessment of its efficiency. 
it is hard to say that the development of administrative procedural law in Slovenia so far represents a momentum of modernization although it follows modernization trends and certainly does not represent a development hindrance.

\subsection{Comparison of the Slovenian GAPA with EU and Council of Europe principles}

The administrative procedure is, above all, a constitutionally supported guarantee against the abuse by superior authoritative bodies in the relation toward individual natural or legal persons. Below is a comparison as to whether and how the Slovenian GAPA (1999-2010) complies with international standards, particularly as regards fair procedure.

It can be concluded that at a normative level, the Slovenian regulation fully complies with international standards (except, maybe, in the event of self-incrimination), since all international safeguards are defined as basic principles in the sense of value orientations, interpretation frameworks of rules, or "supra-rules", which, under Article 22 of the Constitution and Article 3 of GAPA, also apply to all administrative areas. More so, there is a considerable number of implementing rules to make said principles operational, which - considering the potential threats to public interest - is deemed exaggerated in certain cases.

In order to assess the level of protection of parties' rights in practice, here are some empirical data on the use of legal remedies and court statistics in administrative matters. Around 10 million first-instance administrative decisions are issued every year in Slovenia, $3 \%$ of which are challenged by appeal in administrative procedure (the percentage varies depending on the year, the above figure applies to 2008 and 2009, more in Kovač 2010a). A further share of completed administrative acts - up to 3,000 per year - is challenged in administrative dispute, while the parties file around 500-600 constitutional complaints against final decisions in administrative matters; the number of appeals and suits varies, yet slows down over time. The success of the parties is of course much more modest - empirical data show that at all levels of legal protection only $20 \%$ of appellants or plaintiffs succeed. This also implies a decreasing degree of citizens' trust in the state (Toš 2009, 395). The level of public trust in the state and its institutions was $34 \%$ in 1992, $44 \%$ in $2000,35 \%$ in 2005 and $24 \%$ in 2009. Currently, citizens mostly trust the police (40\%). As regards the legal system, $45 \%$ of the respondents express an overall trust in the system and $40 \%$ trust only in part. Hence, Slovenia records a low share of unsatisfied users, since the degree of regulation and the system of control mechanisms are evidently more than satisfactory. In Slovenia, administrative procedural law efficiently protects the rights of the parties, which might occasionally go to the detriment of the efficiency of the procedure or decision-making as such. 


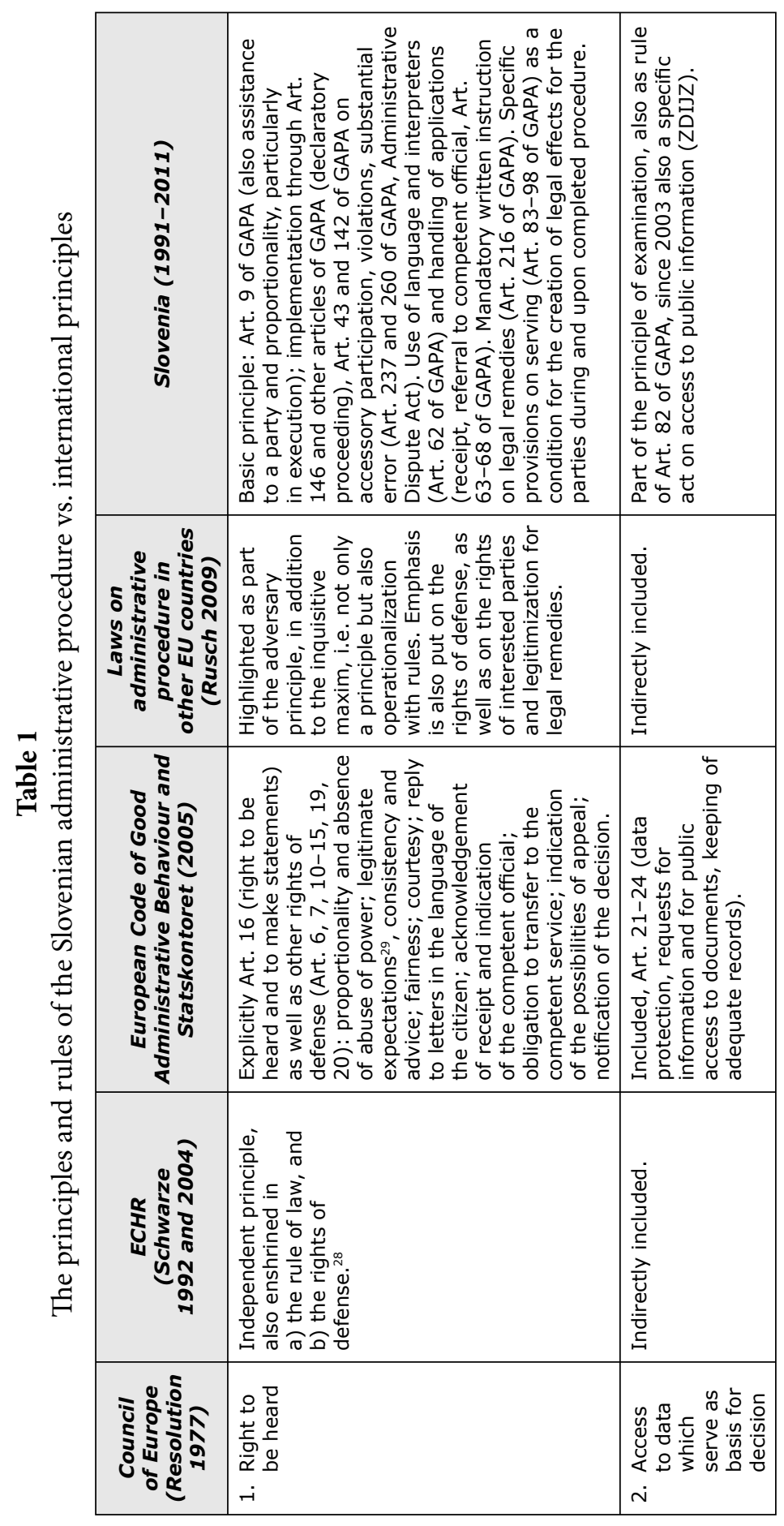

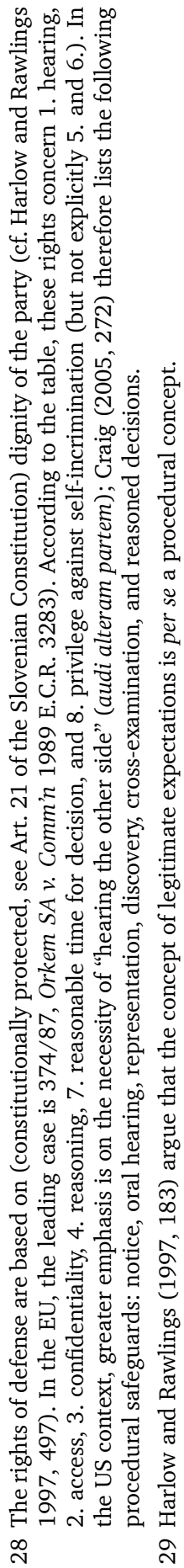




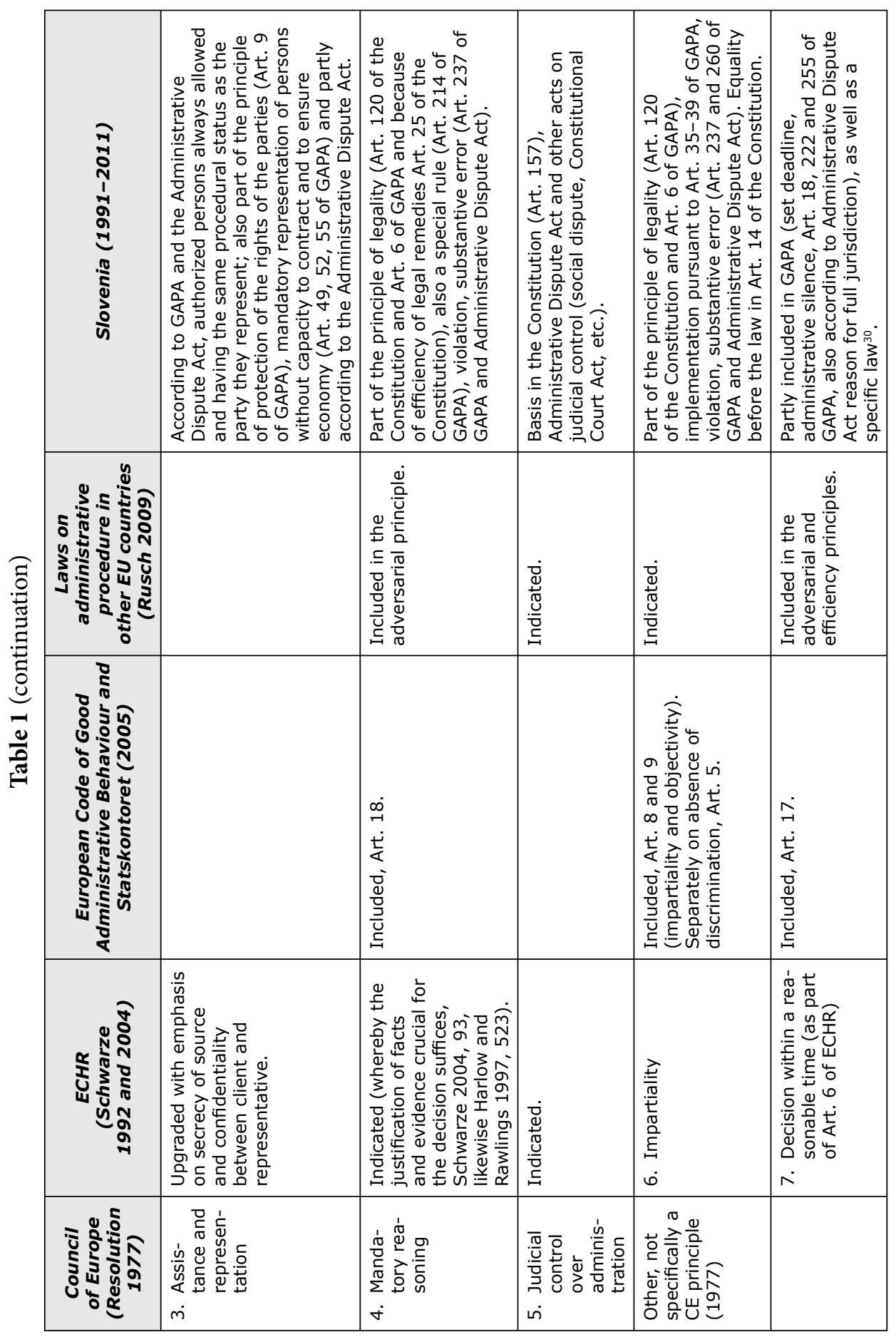




\subsection{Overall assessment of the Slovenian regulation according to GAPA}

If administrative procedural law in Slovenia is to be modified, particularly the amendments to GAPA should be preceded by an assessment of the state of affairs to determine whether the existing regulation corresponds to the present social reality and to the goals pursued by the authorities. After that, if necessary, alternative solutions as to what and how to amend should be designed in order to minimize the gap between the existing and the desired regulation. The needs in real social life are in fact the main incentives for more or less radical and rapid changes of administrative procedural law - and even of the legal nature of public law relations - throughout the world. For the same reasons, the question of amending administrative procedural law arises also in Slovenia.

Within the context of modernization of the Slovenian public administration, GAPA can be analyzed by means of a SWOT analysis - an adequate method for strategic thinking in times of major changes, whereby the first two elements (strengths and weaknesses) relate to the present while the other two (opportunities and threats) refer to the future.

A modern GAPA (and the entire system of administrative procedural acts) is the one that proactively pursues the development of administrative culture according to the theory of rationality or efficient administration and regulation, inasmuch as it is able to implement the social values in space and time. Thus, positive administrative law should do more than merely follow a general reform of the public sector or a medium- or long-term strategy of the government, let alone halt the development of public administration in the country (or a supra- or infra-national community) by preserving the traditional yet obsolete modus operandi of administrative bodies. According to Koprić and Đulabić, modernization of administrative procedure is only present if the new concepts about the role of the administration in the society are complied with and if technical upgrading of the administration is possible, whereby the illusion that any change of law means improvement should be abandoned $(2009,27)$. In any case, examining the positive and negative aspects indicated in the table above, it needs to be underlined that strengths lead to opportunities whereas weaknesses lead to threats, while weaknesses and threats together prevent opportunities. Therefore, amending the Slovenian system of administrative procedural law - which, after all, is functioning satisfactorily - might be rather premature at the moment. If and when the situation calls for a more radical consideration, a multi-level model of regulating administrative procedures is suggested below. Such a model would preserve the traditional foundation of administrative procedure, i.e. balanced protection of parties' rights and public interest, and simultaneously represent the driving force of modernization of the Slovenian public administration rather than being a mere follower of strategic reforms and activities. 
Table 2

SWOT analysis of the Slovenian GAPA (1999-2010) as basis for a redefinition of the regulation

\section{Strengths:}

- traditional regulation, i.e. continuity of implementation;

- regulation according to GAPA complies with all international principles of fair procedure and with the need for efficiency of administration;

- observance of GAPA in practice provides for democracy in the relations;

- well-functioning administrative (and constitutional) judiciary in administrative matters; its (predominantly) consistent decisions are (normally) observed by the administration.

\section{Weaknesses:}

- over-regulation;

- only partial suitability of GAPA for public services:

- sector-specific laws (and even implementing acts) interfere with the system of general administrative procedure, sometimes unjustifiably, partially and without consideration of the unsoundness of decisions and inequality of the parties before the law;

- (too) long duration of procedures despite the program to reduce backlogs (in the past five years); quite often the administrative system fails to issue a final decision within a reasonable time (with due consideration of the rapidly changing situation on the market);

- individual bodies operating bureaucratically rather than as part of the system. ${ }^{32}$

\section{Opportunities:}

- GAPA as momentum of progress and modernization of public administration (promoting partnership, introducing a culture of openness, etc.), in response to social reality (economic crisis, partnership trends, decentralization, deregulation, etc.);

- multi-level regulation depending on the need to protect the rights of the parties and public interest, with less norms and protection when relations are not conflicting;

- GAPA perceived as a tool for a legitimate and upgraded work of public administration;

- integration of key acts of administrative procedural law into a system (GAPA, Administrative Dispute Act, Access to Public Information Act, Public Administration Act, Civil Servants Act, Local Self-Government Act, etc.).

\section{Threats:}

- (too) low level of maturity among employees (and politicians) within the administrative apparatus, who might not understand the revised GAPA or implement it according to the principles of good governance;

- questionable impact of GAPA amendments on special administrative regulation in sector-specific laws; indispensable corresponding amendments.

Source: author's perceptions (based on case law and examples from Kovač, Remic and Sever 2010).

32 In the most extreme case even in a Kafkaesque style, when the body acts based on a variety of forms of conduct as an administrative apparatus. Such an institutional framework is bureaucracy, claiming legitimacy even in the absence of such (Ferk 2007, 16). 


\section{A multi-level model of regulating administrative procedures - tomorrow's regulation of Slovenia?}

Based on the analysis of the current state of affairs, the development of sciences (administrative science, administrative law, political science, etc.) and experience in comparative law, an integral approach to the further regulation of GAPA (and special administrative procedures) is suggested, although a considerable degree of political consensus and cooperation of professionals - characteristic only of major social changes - is necessary for its implementation. There are several indications for amending the regulation of administrative procedure, the most important being the role of administrative procedure, i.e. if and when this is necessary to balance public interest and the interests of the parties. If the entire concept of GAPA and the related administrative procedural law is to be subject to change - as a result, for example, of the deepening of the global economic crisis or changed social-development players according to the theory of good governance - it would be theoretically wise to address the issue at three levels.

Firstly, it needs to be clearly established when exactly a certain issue is deemed an administrative matter (in terms of substance rather than according to provisions of a sector-specific act) or a matter to be regulated by GAPA because of the relatedness of the subject of decision to the public interest. Thus, the concept of administrative or other public-law matter, together with the extent of application of GAPA, needs to be defined, which is currently - based on Articles 3 and 4 of GAPA - inappropriate since due to the inclusion of public-service providers in Article 3(3), GAPA applies subsidiarily to all service activities, although it should be the case law (with sporadic cases) to determine what is to be regulated mutatis mutandis by GAPA, given the type of procedure and the applicable principles or rules of GAPA. A similar classification is offered by Schuppert $(2011,298)$, stressing the importance of different approaches in the basic administrative processes or public tasks, if they involve classic state monopoly (e.g. security issues) on the one hand or welfare or public services on the other. In fact, non-statal bodies do not carry out administrative procedure as a systemic function but rather as an individual task, usually according to the principle of connexity or in relation to their primary activity (care for the local population, providing public services, exercising state or municipal public authority). In the relations toward the parties, such bodies are formally equal to state (authoritative) bodies, although they are not structurally part of state administration, which logically makes such relations different. Even more important - when deciding on the rights, legal interests and obligations of their users - there is an abstract or even non-existing collision with public interest, although the purpose of GAPA is in fact to resolve such antagonism. The parties are nevertheless obliged to file applications for the recognition of their rights, since it usually concerns positive rights, implemented based on a general norm only in a specific procedure and further on in the real world. Given said differences - bod- 
ies outside the state administration and the degree of contestability of relations - it needs to be assessed whether and to what extent GAPA should apply in such cases. The fact that the provider of public service is not a provider of authority does not matter since in the event of positive rights, no authority is provided; the sanction in such a case is not authoritative coercion but only its denial to recognize the user's right; yet nevertheless the public service provider acts as the stronger party in this relation, and the user needs at least a minimum procedural protection (Trpin in Koprić and Đulabić 2009, 56).

Secondly, we need to determine the basic minimum set of principles and rules of the "basic" GAPA, which is to apply to any provider of public tasks, either authoritative or service tasks, as soon as they - in the relation with private parties - act on behalf of the state or other public-law community engaged in the protection of public interest. Based on comparable experience, this involves fundamental principles and certain rules on the status of the parties or interested subjects, communication between participants in the procedure, and legal remedies to challenge administrative decisions or acts and their omissions - altogether up to 50 provisions. Consideration should be given to the definition of additional or redefinition of the existing basic principles (e.g. highlight the importance of proportionality or add the principle of openness and transparency, as proposed for the right to access to public information in the sense of informal supervision over the work of the administration and thus strengthening democracy by McCubbins et al. 2007, 19, similarly Trpin 2006). Also relevant is the fact that no GAPA provision is more important than another - however, in the event of a violation thereof, the legislature may define that inconsistency with certain provisions (with a low evidence standard of the appellant) is deemed a key procedural error, making the final act (formally) illegal (despite its accuracy in terms of substantive law) (cf. Schwarze 2004, 97). To conclude, among the basic principles and rules, this Act (as minimum law) should also define absolute violations of procedural law infringing upon the concept of fair and just procedure.

Finally, two groups of administrative matters subject to GAPA should be defined, depending on the level of their contestability or contentiousness. Where the level of collision between the interest of the party and public interest or contrary interests of third parties is at least potentially expressed or evident at first glance (e.g. tax raising, imposing obligations to parties, or restricting the recognition of rights), a broad, "additional" GAPA should apply besides the basic act, e.g. with 50 additional provisions regulating participants in the procedure, communication, etc. The other group of administrative matters, where additional regulation would not be necessary, is to be dealt with in mutual or contractual administrative relations without additional formalization (e.g. decision adopted without issuing the relevant act, or issuing written acts with reasoning only when the request of the party is denied). There are in fact administrative relations where public interest only refers to the regulation of certain relations without the state or municipality having any 
special interest in the matter, thus there is no need for issuing an administrative act when the public interest complies with and is as strong as the interest of the party (Jerovšek 2000, 171). The need for regulating the relations among the participants in the procedure should be proportionate to the level of conflictuality as well as to the weight of intervention, considering that greater intervention requires higher protection of the parties (cf. Harlow and Rawlings 1997, 504, 516). There is also the possibility for matters and procedures to move from conflictual to contractual, as a form of mediation.

\section{Conclusion}

In Slovenia, administrative procedural law is defined as hard law because of the prevailing understanding of GAPA as a tool for protecting the rights of the parties from abuse of authority. This gives GAPA a considerable legal and social importance. At the same time, however, there is a possibility of missing the opportunities offered by procedural law for modernizing the public administration toward the development of social partnerships.

In terms of transparency, legal certainty and consolidation of administrative relations, a frequent (particularly partial) modification of administrative procedural law, especially GAPA, is not advisable; nevertheless, in times of major social changes (e.g. creation of an independent state, transformation of the economic system, full EU membership, or the global economic crisis after 2007), the concept of a new regulation of public administration in general is to be considered. For this purpose, the competent persons - in cooperation with the expert public and with the objective of optimal legitimacy - wish to modify GAPA. To start with, the Slovenian GAPA could be modified by reducing the number of articles and provisions, since the original wording of the Act with 325 articles is definitely over-regulated and in practice often leads to failure to comply with several provisions (following the "more is less" principle, the Act should contain only the basic principles and rules). Even more important are changes of subject matter, e.g. by putting greater emphasis on the transparency and economy of operations (eliminate unnecessary actions for the protection of public interest among administrative bodies, transfer more investigation powers to bodies, reduce deadlines in the procedure and introduce sanctions for violations, etc.), the redefinition of competent bodies by reducing state administration, simplified and mutual regulation of relations for publicservice providers, the introduction of new institutions in light of the partnership aspirations of the administration (mediation and other forms of alternative dispute resolution, administrative contracts, etc.).

The current Slovenian GAPA is adequate, with considerable potential for further development. First, it is possible to redefine the subject matter of the Act by including only the basic principles and highest rules necessary for a balanced pro- 
tection of the rights of the parties and public interest, while the remaining rules should be deregulated or delegated to the executive or left to (only indispensable) interventions by sector-specific laws. Second, because of the focus on merely Weberian dimensions of public administration - the judicial administration should in fact cover both authoritative and service activities, and in structural terms it is implemented largely outside the apparatus of a repressive state administration. As regards service activities in the relations between the holders of the rights and obligations and providers of public services (even private with concessions), theory and practice worldwide note that considering the level of contestability and threat and the consequent need for the protection of public interest, this cannot be equally regulated.

\section{References}

Androjna, Vilko and Erik Kerševan. 2006. Upravno procesno pravo [Administrative Processual Law]. Ljubljana: GV Založba.

Breznik, Janez, Mira Dobravec Jalen, Marjanca Faganel, Erik Kerševan, Gorazd Kobler, Kristina Ožbolt, Jasna Pogačar, Zdenka Štucin and Boštjan Zalar. 2008. Zakon o upravnem sporu (ZUS-1) s komentarjem [Administrative Dispute Act with comments]. Ljubljana: GV Založba.

Cananea, Giacinto Della. 2003. "Beyond the State: The Europeanization and Globalization of Procedural Administrative Law.” European Public Law 9 (4), 563-578.

Considine, Mark, and Kamran Ali Afzal. 2011. "Legitimacy." In Mark Bevir (ed.). The SAGE Handbook of Governance. Los Angeles, London, New Delhi, Singapore, Washington DC: Sage, 369-385.

Craig, Paul. 2005. "Administrative Law in the Anglo-American Tradition." In B. Guy Peters and Jon Pierre. Handbook of Public Administration. London, Thousand Oaks, New Delhi: Sage, 270-275.

European Ombudsman. 2005. "European Code of Good Administrative Behaviour. Luxemburg: Office for Official Publications of the European Communities." Available at http://www.ombudsman.europa.eu/code/pdf/sl/code2005_sl.pdf (last accessed 3 May 2011).

Ferk, Janko. 2007. Pravo je "Proces": O Kafkovi pravni filozofiji [The Law is "Process": On Kafka’s legal philosophy]. Ljubljana: GV Založba.

Godec, Rupko (ed.), Lovro Šturm, Gorazd Trpin, Rajko Pirnat and Mitja Horvat. 1993. Upravni zbornik [Administrative Proceedings]. Ljubljana: Institute of Public Administration at the Faculty of Law of Ljubljana.

Harlow, Carol and Richard Rawlings. 1997. Law and Administration. London, Edinburgh, Dublin: Butterworths. 
Hopkins, W. John. 2007. "International Governance and the Limits of Administrative Justice: The European Code of Good Administrative Behaviour." New Zealand University Law Review 22 (4), 710-727.

Jerovšek, Tone. 2000. "Nadomeščanje upravnega akta s sporazumnim urejanjem razmerij" [Replacing Administrative Act with Contractual Relationships]. Paper presented at the VI. Days of Slovene Public Administration, September, in Portorož, Slovenia.

Jerovšek, Tone. 1999. Zakon o splošnem upravnem postopku (ZUP) z uvodnimi pojasnili [General Administrative Procedure Act (GAPA) with introductory remarks]. Ljubljana: Uradni list RS.

Jerovšek, Tone and Polonca Kovač. 2010. Upravni postopek in upravni spor [Administrative Procedure and Administrative Dispute]. Ljubljana: Faculty of Administration.

Jerovšek, Tone and Polonca Kovač. 2007. Posebni upravni postopki [Special Administrative Procedures]. Ljubljana: Faculty of Administration.

Kerševan, Erik. 2003. "Uporaba postopka pri odločanju o javnopravnih zadevah s strani nosilcev upravnih funkcij" [Application of Procedure in Deciding on Public Law Matters by Holders of Administrative Functions]. Javna uprava 39 (4), 489-502.

Koprić, Ivan. 2005. "Administrative Procedures on the Territory of Former Yugoslavia." Paper presented at the Regional Workshop on Public Administration Reform and EU Integration, in Budva, Montenegro. Available at http://www. oecd.org/dataoecd/52/20/36366473.pdf (last accessed 20 April 2011).

Koprić, Ivan, Vedran Đulabić et al. (eds). 2009. Modernizacija općeg upravnog postupka i javne uprave u Hrvastkoj [Modernization of General Administrative Procedure and Public Administration in Croatia]. Zagreb: Institut za javno upravu in Društveno veleučilište u Zagrebu.

Kovač, Polonca. 2010a. "Effectiveness of Legal Remedies in Administrative Proceedings (the Case of Slovenia)." Paper presented at the $32^{\text {nd }}$ EGPA Annual Conference, September, in Toulouse, France. Available at http://egpa2010. com/documents/PSG10/Kovac.pdf (last accessed 4 May 2011).

Kovač, Polonca. 2010b. "Smernice razvoja regulacije upravnih postopkov" [Development Trends in Regulation of Administrative Procedures]. Paper presented at the XVII. Days of Slovene Public Administration, September, in Portorož, Slovenia.

Kovač, Polonca. 2006. “The Impact of International Principles, Standards and Praxis on (Slovene) Administrative Procedure." Riv. ital. dirit. pubblico comunitario (Testo stamp.) 16 (5), 919-945. 
Kovač, Polonca, Matjaž Remic and Tina Sever. 2010. Upravno-procesne dileme pri rabi ZUP [Administrative Procedure Dilemmas in the Application of GAPA]. Ljubljana: Uradni list RS.

McCubbins, Mathew D., Roger G. Noll and Barry R. Weingast. 2007. "Administrative Procedures as Instrument of Political Control." In Cary Coglianese and Robert A. Kagan (eds). Regulation and Regulatory Processes. Hampshire, Burlington: Ashgate, 3-20.

Pavčnik, Marjan. 2007. Teorija prava: Prispevek k razumevanju prava [Theory of Law: Contribution to Understanding the Law]. Ljubljana: Cankarjeva založba.

Pitschas, Reiner and Harald Walther. 2008. Mediation im Verwaltungsverfahren und Verwaltungsprozess. Frankfurt am Main, Berlin, Bern, Brussels, New York, Oxford, Wien: Peter Lang.

Rusch, Wolfgang. 2009. "Administrative Procedures in EU Member States." Paper presented at the Conference on Public Administration Reform and European Integration, 26-27 March, in Budva, Montenegro. Available at http://www. oecd.org/dataoecd/49/34/42754772.pdf (last accessed 15 April 2011).

Schwarze, Jürgen. 2004. "Judicial Review of European Administrative Procedure." Law and Contemporary Problems 68, 84-105.

Schwarze, Jürgen. 1992. European Administrative Law. London: Sweet and Maxwell.

Schuppert, Gunnar Folke. 2011. "Partnerships." In Mark Bevir (ed.). The SAGE Handbook of Governance. Los Angeles, London, New Delhi, Singapore, Washington DC: Sage, 286-299.

Schuppert, Gunnar Folke. 2000. Verwaltungswissenschaft (Verwaltung, Verwaltungsrecht, Verwaltungslehre). Baden-Baden: Nomos Verlagsgesellschaft.

Statskontoret. 2005. "Principles of Good Administration in the Member States of the European Union." Available at http://www.statskontoret.se/upload/Publikationer/2005/200504.pdf (last accessed 15 April 2011).

Šturm, Lovro. 1997. Zbirka primerov iz ustavnega upravnega prava I: Vezanost uprave na zakon [Compendium of Cases from Constitutional Administrative Law I]. Ljubljana: Uradni list RS.

Toš, Niko. 2009. "Vrednote v prehodu" [Values in Transition]. In IV. Slovensko javno mnenje 2004-2009 [IV. Slovenian Public Opinion 2004-2009]. Ljubljana: Faculty of Social Sciences, 11-46.

Trpin, Gorazd. 2006. "Postopek občevanja med državljani in organi javnih oblasti: novi koncept splošnega upravnega postopka" [Communication between Citizens and Public Authorities: New Concept of General Administrative Procedure]. Javna uprava 42 (2/3), 257-272. 
Ziller, Jacques. 2005. “The Continental System of Administrative Legality." In B. Guy Peters and Jon Pierre (eds). Handbook of Public Administration. London, Thousand Oaks, New Delhi: Sage, 260-268. 